\title{
Role of Reference Librarian in Public Relations Activity in University Library
}

\author{
Rikarda Ratih Saptaastuti \\ ratih@unika.ac.id
}

\begin{abstract}
The library cannot achieve its goals without cooperation with the internal and external public. Therefore, libraries need $P R$ (public relations) in their efforts to achieve their goals. The activity of the university library is directly or indirectly related with the $P R$ activity since it is the part of $P R$ activities to promote the image and the use of the library. The implementation of public relations activities in libraries has actually been performed by reference librarians. Reference librarians can use a variety of printed and online media, or convey information directly related to library services to users. With the recent development of information technology, using online search tools to seek information is more preferable by users than asking the reference librarian. Though online information tracking tool to organize information is more sophisticated presenting for users, users will still need libraries and referral services to find relevant information, as there are things that are not provided by online services such as selection, organization, provision of access, interpretation of relevant information, which can only be done by reference librarians. Reference librarians perform their duties by serving users in providing answers to questions or guiding users, and by creating awareness that the services provided by the library help promote maximum utilization of the library. PR officers through reference librarians attempt to attract the users' attention through the provision and dissemination of information, and to serve as well as a liaison between the libraries with the users. PR becomes a necessity in libraries as $P R$ activities will drive library function effectively and help promote library services more optimally.
\end{abstract}

Keywords: $\quad$ Public Relations, Library of Higher Education, Reference Librarian 


\section{Preliminary}

Activity of Public Relations (PR) in the library is a planned and structured effort to build and maintain mutual understanding between the libraries with the public (the user). PR is an extension of the organization to communicate a positive image of the library to the public ${ }^{1}$. Public relations activities in the library are concerned with promoting the library programs, available services, and information resources. PR needs to be empowered in a library as an effort to build harmonious relationships with users and to establish a library image ${ }^{2}$.

Currently, PR activity in the library has not been optimally done, especially in the university library because it has not emphasized the important function of public relations activities.

According to Dodsworth, the university library assists the academic community as an internal public to obtain all relevant sources of necessary information for the benefit of teaching, learning, research, including the public as an external public of the university ${ }^{3}$.

This means that the goal of any academic institution cannot be achieved without the PR. The activity of the university library directly or indirectly is the PR activity; it is done to promote the image and the use of the library. Implementation of PR activities has actually been done through Reference Librarian

The university library offers a variety of services that the user needs to know, the task of the reference librarian to inform the public about the library's services. The reference librarian uses media such as brochures, library magazines, or conveys information directly related to library services to users. The reference librarian is referred to as a PR officer because he/ she represents the image of the library, where the tasks he/she deals always

\footnotetext{
${ }^{1}$ Aitufe, T.A. 1993. "Public Relations in Academic Libraries." Library Review 42 (2).

${ }^{2}$ ibid

${ }^{3}$ Doodsworth, E.M. 1998. "Marketing Academics Libraries: A Necessary Plan." The Journal of Academic Librarianship 24 (4).
} 
with the user. As Pena and Green(Pena, David. S \& Green 2006) ${ }^{4}$ point out, reference librarians have four main functions: instructing users how to use libraries, answering users' questions, suggesting information sources, and promoting libraries to users. Reference librarians are an intermediary between users and libraries; he can easily know what the user needs and what libraries have.

PR in the university library is necessary. It is true that all librarians involved in library activities should be involved in public relations activities, but librarians whose job directly relates to users and performs more public relations activities than others are reference librarians. A PR officer in an organization is an impression maker and an image of the organization, in which case the reference librarian has a library representative role to the user more than any other librarian partners.

\section{Discussion}

The interests of any organization, whether commercial or noncommercial to public relations activities, cannot be avoided. The existence of PR cannot be prevented, regardless of whether we like it or not. PR consists of all forms of communication held between the organization and anyone who has contact with it. PR is a management function that builds and maintains good and beneficial relationships between companies and the public that affects the success and failure of the company. ${ }^{5}$

Meanwhile, according to Jefkins, public relations is all forms of planned communication, both inside and outside, between an organization with all audiences in order to achieve specific goals based on mutual understanding. ${ }^{6}$

$\mathrm{PR}$ is in principle an overall effort done in a planned and sustainable in order to create and maintain goodwill (goodwill) and mutual understanding between organizations with all its audience.

\footnotetext{
${ }^{4}$ Pena, David. S \& Green, Samuel. S. 2006. "Personal Relations Between Librarians and Readers." Journal of Access Services 4 (1/2)

${ }^{5}$ Cutlip, Scott (et.al). Effective Public Relations. New Jersey: Prentice Hall, 2001.

${ }^{6}$ Jefkins, Frank. Public Relations. Jakarta: Penerbit Erlangga, 2004.
} 
Public relations are a function of management in the organizational structure and become part or division of the organization or company. Therefore, the purpose of public relations as a structural part of the organization is inseparable from the objectives of the organization itself. This is what Oxley calls one of the principles of public relations, which states "The purpose of public relations is clear and absolutely contributes to the objectives of the organization as a whole. ${ }^{7}$

Oxley says the goal of public relations itself is to seek and maintain mutual understanding between the organization and its public. ${ }^{8}$

Public relations activities will bring enormous benefits to the organization of reputation and image, also called the greatest asset in the organization.

\section{Communication and Public Relations}

Communication is said to be effective when people can convey what it means. Effective two-way communication is seen as the only tool in public relations management that is utilized in developing an organization. For PR, feedback through public opinion created will bring improvement, change and development as a result. The most valuable and useful way is the open attitude to receive feedback through the monitoring of the parties concerned by Maksum in "Perpustakaan Dalam Perspektif Public Relations (Library in the Perspective of Public Relations)."

A communication can be said to be effective when it encompasses five criteria: understanding, fun, influencing attitudes, improved relationships and public relations actions ${ }^{9}$ which are a bridge to build harmonious relationships between internal and external public within an institution or company. Therefore, communication and PR have a very important role, including in the world of libraries. In addition to creating harmonious relationships and

\footnotetext{
${ }^{7}$ Oxley, Harold. The Principle of Public Relations. Philadephia: Kogan Page Limited, 1987.

${ }^{8}$ loc.cit

${ }^{9}$ Mulyana, Deddy. Komunikasi Efektif: Suatu Pendekatan Lintas Budaya. Jakarta: Remaja Rosdakarya, 2004.
} 
building public trust and positive image, PR also plays a role in developing marketed products and products, advertising, and rebuilding negative opinions through explanations or advocates of poor views from the public by presenting various data, facts, and the actual information. Internal PR activities are conducting analysis and improvement of self, while external activities are holding statements.

According to Effendy in Maksum, the characteristics of PR are as follows ${ }^{10}$ :

1. PR is a communication activity in an organization that takes two ways reciprocal communication

In public relations, communication is the dissemination of information, with the reciprocity of public opinion.

2. The PR function is attached to the management process.

$\mathrm{PR}$ activities are focused on handling the communication among people. The targets of public relations activities are public, both internal and external, to create and maintain harmonious relationships between institutions and the public inside and outside.

3. In operational activity, PR should foster a harmonious relationship and prevent the occurrence of psychological barriers. Therefore, PR should have a favorable attitude, goodwill, tolerance, mutual understanding, mutual confidence, mutual appreciation, and good image.

\section{The importance of public relations in the University Library}

The function of university libraries is to support the implementation of Three Principles of Higher Education (Tri Dharma Perguruan Tinggi) by providing scientific information for students, lecturers and staff as well as external users. The ultimate goal of any university library is to satisfy its users by providing materials to meet educational, research and service needs. The library cannot achieve its objectives without goodwill and cooperation

${ }^{10}$ Maksum. "Perpustakaan Dalam Perspektif Public Relations." Jurnal Perpustakaan Pertanian 18 , no. 2 (2009). 
with the public both internally and externally. Thus, libraries need public relations in an effort to achieve their goals. A library program, a complete book collection, service development and IT equipped with PR activities are a necessary requirement.

According to Aitufe the need for public relations activities in academic libraries is as follows ${ }^{11}$ :

1. Librarian relationships with the public will affect and create confidence to provide services to users in various ways, for example by making users understand and know the library services and policies.

2. Librarian relationships with the public helps in opening better and more complete insights and knowledge. This helps to make the relationship better between the librarian and the public.

3. PR encourages better cooperation and relationships among the team of librarians. This relationship can lead to mutual collaboration.

4. PR helps to make a better relationship between librarian and user. This provides an opportunity for librarians to create a good library image and improve the utilization of library services and resources.

5. PR helps to receive and collect opinions or comments from external public and convey such information to library management as input and consideration.

6. The PR in the university library will help all public (internal and external) know about library policies, functions and services and improve library staff's knowledge and understanding.

7. PR can help librarians get more support from their central organization in terms of personnel, budget and infrastructure. Good imagery in the libraries and librarians certainly has a positive impact on the parent organization by giving the appreciation that is needed by librarians and librarians.

8. Not all academic community knows about library services and what benefits will be obtained, then PR will help publish and promote library

${ }^{11}$ loc.cit 
functions and services.

9. In general, the image of the university library is not yet optimal. PR is required to present the library services through communication with the users, to change the user image of the library for the better.

\section{Competence of Reference librarian}

There are various library services for the user, one of which is the reference service. The University Library Guidelines mention reference services are activities to help users search for information in various subjects. ${ }^{12}$ Through reference services, users are assisted to quickly find information, track information more specifically and with a wider choice of subjects, and make the most of available tracking tools available. From that sense, the referral service is the service that is closest to meeting the needs of users for information.

Reference services help users to find the right information to suit their needs. When viewed from the three general functions of the library namely procurement, organizing and dissemination of information then the reference service is a service that runs the function of dissemination of information. Thus, the reference service is a service that must exist in each library. The reference service will work with the human resources providing the service, the reference librarian. According to Katz, there are five important competencies that must be possessed by reference librarians - knowledge of bibliographic tools, interpersonal skills to users, the ability to select and evaluate materials used from the library, the ability to conduct referral interviews, and helping users to find what they need in the library. ${ }^{13}$

Reference services allow for active communication between the user and the library because the nature of the service is to answer the question while providing the information the user wants. As a key individual in the reference service, the reference librarian must have a number of competencies required to support his work.

${ }^{12}$ Departemen Pendidikan Nasional. Pedoman Perpustakaan Perguruan Tinggi. Jakarta: Departemen Pendidikan Nasional, 2004.

${ }^{13}$ Katz, William. Personnel Issues in Reference Services. New York: The Haworth Press, 1986. 
Competence of reference librarian according to Katz, including ${ }^{14}$ :

1. Knowledge of research methodology

2. General knowledge of information resources

3. Specific knowledge of a subject

4. Understanding of technical services including cataloging and procurement

5. Knowledge of one or more online search systems

6. Ability to teach

7. Expertise in management

8. Speaking skill

9. Consultancy expertise

10. Sensitivity

11. Dynamism in groups

ASERL mentions that librarians must have intellectual curiosity, flexibility, adaptability, persistence, and a willingness to keep trying. In addition, librarians also need to have skills in communication and they do lifelong learning, and personal career development ${ }^{15}$.

\section{The Role of Reference Librarians and Their Relationships with Users}

Reference librarians have an inherent obligation to provide information services to support educational, research, service and recreation efforts for their users in accordance with library mission. Reference librarians establish mutual relationships with users; serve them cordially so that users do not feel reluctant to ask for referral help. The service of sympathy and empathy, full of vigor and cheerfulness should be demonstrated by reference librarians to establish two-way communication and be effectively established between librarians and users.

According to Pena and Green, a reference librarian has four functions including ${ }^{16}$ :

\section{${ }^{14} \mathrm{Ibid}$}

${ }^{15}$ ASERL. "Shaping The Future: ASERL's Competencies For Research Librarians." Atlanta, 2000.

16 loc.cit 
1. Giving instruction to the user how to use the library. The role of the instruction itself is meant to help new users learn how to organize libraries, thereby benefiting from the knowledge contained in their collections. Libraries now have more resources in various forms, serving more people in more places and instruction has become a big responsibility for librarians.

2. Answering user requests or questions. In this function, the librarian answers each user's question. In general, there are two kinds of questions. First, the most commonly asked questions by the user are the user asking what he or she already knows such as requesting documents, books, articles or other material. For such questions the librarian may provide catalogs, indexes, bibliographies or other similar materials. Second, the user asks for information without any knowledge of a specific source. The question will trigger a consultation or referral interview.

3. Assisting users choose information sources. This function is the relationship between the librarian's knowledge of the collection and the information needs of the users. With the development of information technology, where electronic information sources can be accessed, reference librarians can provide recommendations for sources and search strategies to users whenever they interact with them.

4. Promoting library to user community. Pena and Green realize that the library is one part of the larger community and the success of the library depends also on the recognition of its parent institution. The library should show its value to the parent institution. The best way is through a reference librarian who is available to help users who seem to need help. Readily available reference librarians for users can make people better understand, appreciate, and support the work of the librarian.

Recently, with the development of information technology, using online information search tools is more user-selected to seek information than asking the reference librarian. As good as any online information search tool presented to organize information for users, users will still need 
libraries and referral services to find relevant information. Because there are still competencies that are not provided by online services, such as selecting, organizing, providing access, interpreting relevant information, these can only be done by reference librarians. The librarian will continue to perform the fundamental role required by the user. Therefore, to make the user aware of the existence of the library with various programs, collections and services, then the reference librarian needs to do promotion.

\section{Role of Reference Librarian as PR}

A PR officer is the person who manages policies and programs related to promoting and maintaining relationships with local media and community groups. The PR officer is the liaison that unifies the activities of the organization carried out separately. ${ }^{17}$

Reference librarians perform their duties by serving users providing answers to questions or guiding users, creating awareness of the services provided by the library will help promote maximum utilization of the library. Reference librarians act as an intermediary between users with the source of information the library provides to users.

Reference librarians as PR officers try to attract the attention of users through the provision of information. Reference librarians disseminate information that has been obtained to serve and function as a link between libraries and users. The activity of the reference librarian is the same as that of the public relations organization or company promoting the library using PR media such as brochures, web sites, library exhibits, newsletters or library magazines, social media, etc.

Each library that functions PR has a relationship with the community or the users it serves. Reference librarians who also serve as a PR will ensure that potential users and potential users of the library have extensive access by actively promoting. Reference librarians collect information relating to library activities, then organized for the purpose of publication and promoting the library's image.

\footnotetext{
${ }^{17}$ loc.cit
} 


\section{Conclusion}

Activities of Public Relations (PR) in the library are a planned and structured effort to build and maintain mutual understanding between the library with the public (the user). In an effort to build and maintain mutual understanding between the library and the public (the user), the public relations activities are needed in the college library. PR activities will help build the image and position of libraries among the academic community. There is a need for a university library for public relations activities, as it will help for better relationships between librarians and users. To achieve the goals and objectives of libraries, librarians, especially reference librarians should have a serious concern about public relations activities.

The reference librarian also serves as a public relations officer because he/she positions himself/herself as a bridge or link to separate library activities, coordinates library services centered on the referral service counter, and promotes libraries through the provision of information. PR officers through reference librarians try to attract the attention of users through the provision and dissemination of information, serving as well as a liaison between the library with the user. PR becomes a necessity in libraries; PR activities will drive library function effectively and help promote library services more optimally.

\section{Bibliography}

Aitufe, T.A. "Public Relations in Academic Libraries." Library Review 42, (2) (1993). Retrieved from: https://doi.org/10.1108/00242539310027002. ASERL. "Shaping The Future: ASERL's Competencies For Research Librarians." Atlanta, 2000. Retrieved from: http://www.aserl.org/ programs/competencies/.

Cutlip, Scott (et.al). Effective Public Relations. New Jersey: Prentice Hall, 2001.

Departemen Pendidikan Nasional. Pedoman Perpustakaan Perguruan Tinggi. Jakarta: Departemen Pendidikan Nasional, 2004. 
Doodsworth, Ellen. "Information Policies Marketing Academics Libraries: A Necessary Plan.” Journal of Academic Librarianship 24, (4) (1998). Retrieved from: https://doi.org/10.1016/S0099-1333(98)90110-0

Pena, David. S \& Green, Samuel. S. "Personal Relations Between Librarians and Readers." Journal of Access Services 4, (1/2) (2006). Retrieved from: https://doi.org/10.1300/J204v04n01_12

Jefkins, Frank. Public Relations. Jakarta: Penerbit Erlangga, 2004.

Katz, William. Personnel Issues in Reference Services. New York: The Haworth Press, 1986.

Mahmudin. Pengantar Ilmu Perpustakaan. Bandung: Unpas, 2006.

Maksum. "Perpustakaan Dalam Perspektif Public Relations." Jurnal Perpustakaan Pertanian 18, no. 2 (2009). Retrieved from: http:// pustaka.litbang.pertanian.go.id/publikasi/pp182091.pdf

Mulyana, Deddy. Komunikasi Efektif: Suatu Pendekatan Lintas Budaya. Jakarta: Remaja Rosdakarya, 2004.

Oxley, Harold. The Principle of Public Relations. Philadephia: Kogan Page Limited, 1987. 